\title{
Critical Success Factors of Business Intelligence Implementation in Thai Hospitals
}

Suwat Janyapoon, Department of Industrial Engineering, Faculty of Engineering, Mahidol University, Salaya, Thailand

(iD) https://orcid.org/0000-0003-1299-5220

Jirapan Liangrokapart, Department of Industrial Engineering, Faculty of Engineering, Mahidol University, Salaya, Thailand (iD) https://orcid.org/0000-0002-6738-0752

Albert Tan, Malaysia Institute for Supply Chain Innovation, Shah Alam, Malaysia

\begin{abstract}
Business intelligence (BI) has become popular among management executives of different industries. Many publications have mentioned big data and how to use data intelligently. However, little is known about how to successfully implement BI in the healthcare industry. The unique characteristic of this business, which focuses only on quality of care and patient safety, has a big impact on decision-making. This research is based on a literature review and empirical evidence collected from interviews with professionals involved in the healthcare industry. Twenty-four hospital executives and information technology staff who have direct or indirect experience with BI were interviewed. It investigates critical success factors for BI implementation in hospitals and provides insight into the healthcare industry in Thailand. The concept of grounded theory was applied for content analysis. Insights from this research contribute to academia and the healthcare industry by providing first-time evidence of specific factors for BI implementation and guidelines in hospitals.
\end{abstract}

\section{KEYWORDS}

Business Intelligence, Grounded Theory, Hospitals, Implementation, Key Success Factors

\section{INTRODUCTION}

Business Intelligence (BI) refers generally to a technology-driven system that aids organizations in analyzing a variety of raw data from multiple sources, extracting insights that will lead to more effective business decisions (Lath, 2018). BI works by acquiring relevant information from multiple system(s), cumulating it into a database, and then generating meaningful reports to help users (typically, business leaders) to identify strategic opportunities and make smarter decisions. Widely deployed in many industries for its ability to perform data analytics to enable intelligent decision-making, BI facilitates increased customer satisfaction, results in better returns on investment (ROI) and more effective risk management, improves efficiencies, and provides competitive advantages.

Nowadays, healthcare organizations are realizing that data and BI systems are crucial in the decision-making process that will improve patient outcomes and the quality of medical services. 
Although several BI implementation studies in other industries have been conducted, little research has focused on the critical success factors (CSFs) for BI implementation in hospitals (Nguyen, Meredith, \& Burstein, 2018). In data-intensive industries, such as hospitals, the use of BI has been deliberated for over a decade; yet, little is known about how to successfully implement BI in hospitals. Given the unique characteristic of the healthcare business, which centers largely on the quality of care services and patient safety, implementing BI systems can surely enhance organizational competitiveness.

Olszak \& Batko (2012), for example, confirmed that the use of BI systems in healthcare organizations can be a source of competitive advantage, resulting in clear benefits. Specifically, BI systems provide reliable and consistent information from all areas of an organization's activities and that information can then be converted into useful knowledge for rational decision-making and positive business outcomes. As BI is considered an Information Technology (IT) tool used to structure data in hospitals and help to add value for hospital services, the implementation of BI requires thorough considerations of its CSFs. Hence, the following research question is raised: "What are the critical success factors of BI implementation in Thai hospitals?"

In order to achieve the goal of this research, Section 2, the next section, overviews the extant literature on BI implementation success factors among different industries. Following this, an explanation on the adopted research methodology, which includes Grounded Theory concept and the analytic approach, is provided in Section 3. In Section 4, key findings of our study are highlighted visà-vis the identification of specific factors for BI implementation in Thailand hospitals. The validation using triangulation and the discussion of the findings are presented in Section 5. Lastly, Section 6 provides concluding remarks, emphasizing key research contributions, potential study limitations, practical implications, and suggestions for future research directions.

\section{BI IMPLEMENTATION SUCCESS FACTORS IN DIFFERENT INDUSTRIES}

The hospital sector is prime for BI implementation to be studied as it relates to human lives. Many, if not all, countries have experienced a rapid increase in the demand for hospital services, leading to accelerating medical expenditures per capita. In order to provide high-quality services so as to safeguard patient safety, IT systems have been implemented and deployed. However, given the slowmoving nature of the hospital industry, the applications of IT in the healthcare industry has lagged that of most other industries. Meanwhile, the transactions of everyday services in each hospital have created massive amounts of data, which have cumulated in the hospital data warehouse while not being fully leveraged. Even so, selected data have been transferred to external organizations for specific purposes, for example, hospitals in Thailand must submit some data files to the Ministry of Public Health and the National Health Security Office for statistical recordings and reimbursement purposes.

Aside from medical service staff, hospitals also hire IT staff to be responsible for IT-related functions. The shortage of IT staff in hospitals is common in developing countries (Pham, et al., 2016). This problem is compounded in the hospital industry as it requires IT technicians who also understand technical terms that are specific for the health industry (i.e., medical informatics) as it is difficult, if not impossible, for these IT staff with little knowledge of medical terminology to analyze medically related data. Not only would significant time be needed to train the IT staff on acquiring health informatics competencies but allowing IT staff without sufficient knowledge and/or skills to implement IT applications in healthcare environments has the potential to result in serious and/or unexpected medical errors.

Broadly, it is now common for different industries to adopt BI as part of a successful enterprisewide implementation. Many factors are critical for the success or failure of incorporating the BI implementation. Accordingly, relevant bodies of literature have been sourced from the Web of Science, EBSCO, Science Direct, Elsevier, Springer Link, IEEE/IET, and Emerald database over the previous 25 years from 1995 to 2019. Keywords such as "business intelligence", "implementation", and "success factor" were used with papers published in other (non-English) languages, those involving 
disease-specific or procedure-specific, and the non-research papers excluded. After screening titles and abstracts of these publications, a total of 55 citations were chosen for further investigation.

At the beginning state, numerous factors have been extracted from the extant literature; then, those factors that have similar meaning were combined and renamed, with duplicate factors removed. The critical success factors (CSFs) for BI implementation in different industries identified in the literature are highlighted in Table 1.

The most frequent factors found include 'management support,' 'team skills,' 'data management,' 'technology framework,' 'adequate resources, 'project scope,' 'vision and requirements,' 'executive sponsor,' 'strategic alignment,' 'change management,' 'stakeholder,' and 'organization culture' (see Figure 1).

Denic et al. (2016) stated that the implementation of BI may differ depending on the enterprise. This variance may be explained by various factors, from which the BI component is being incorporated, how it is being used, and then from the experience of the enterprise in its implementation. Foshay \& Kuziemsky (2014) found that many healthcare organizations have yet to implement BI systems and there is no existing research to provide a healthcare-specific framework to guide BI implementations. The lack of evidence-based literature focusing on BI implementation in healthcare is also supported by Pham et al. (2016), Loewen \& Roudsari (2017), and Alabaddi et al. (2020). In the Iranian healthcare system, Mosadeghrad (2014) found that important changes are required in a number of dimensions if healthcare organizations are to provide high-quality services.

Although the application of BI system has increased recently, the CSFs of BI system implementation remain poorly understood. Key pointers extracted from the extant literature include:

- Management support is considered as the most important factor for BI implementation. Such support grounds commitment for organizational success (Yeoh, 2008). The key responsibility of management is to set strategy, allocate resources, and encourage staff which affects the information quality and decisions (Watson \& Wixom, 2007). Without a strong management support, BI implementation will not be successful.

- The knowledge, skills and experience of the BI implementation staff are also extremely important. The BI team should be cross-functional and comprises both IT and business personnel. BI Implementation calls for a balance of technical skills within a team, interpersonal abilities and the capacity to work skillfully in undertaking non-trivial tasks in ways that involve good interaction among users (Watson \& Wixom, 2007).

- Data quality and system quality can impact significantly on data management (Watson \& Wixom, 2007) and user satisfaction (Gaardboe, Nyvang, \& Sandalgaard, 2017). The successful integration of data depends on the number and type of source systems, the quality of these systems, the accuracy of data, and the ability for the BI to interface with these systems (Sammon \& Finnegan, 2000).

- The IT infrastructure impacts the BI implementation directly. It does not solely entail the buying of hardware-software but rather it undertakes the complex requirements for suitable resources and infrastructural needs over the long term (Yeoh \& Koronios, 2010). The technical framework should be scalable with respect to additional data sources, attributes and dimensions. Olszak \& Batko (2012) argued that IT infrastructure and technologies impact directly on the success of BI implementations.

- Organizations need to prioritize their use of limited resources while achieving greater value with such uses (Gaardboe \& Svarre, 2018). Anchoring BI needs to ensure the allocation of necessary resources (Yeoh \& Koronios, 2010; Olszak \& Ziemba, 2012; Mosadeghrad, 2014). Such resources include facilities, capital, human, and technical aspects.

- Project management, affecting BI implementation success, helps to ensure user involvement in the process (Olszak \& Ziemba, 2012; Gaardboe \& Svarre, 2018). Hawking \& Sellitto (2010) found 
Table 1. CSFs for BI implementation in different industries

\begin{tabular}{|c|c|c|c|c|c|c|c|c|c|c|c|c|c|c|c|c|c|c|c|c|c|c|c|c|c|c|c|c|}
\hline \multirow{2}{*}{$\begin{array}{c}\text { Critical sucess } \\
\text { factors }\end{array}$} & \multicolumn{28}{|c|}{ Authoss" } \\
\hline & 1 & 2 & ${ }^{3}$ & 4 & 5 & 6 & 7 & 8 & , & 10 & 11 & 12 & 13 & 14 & 15 & 16 & 17 & 18 & 19 & 20 & & & & 24 & 25 & 26 & 27 & 28 \\
\hline $\begin{array}{l}\text { 1. Management } \\
\text { support }\end{array}$ & $x$ & & $\mathrm{x}$ & $x$ & $x$ & $x$ & $\mathrm{x}$ & $\mathrm{x}$ & $\mathrm{x}$ & $\mathrm{x}$ & $\mathrm{x}$ & & & $\mathrm{x}$ & $\mathrm{x}$ & $\mathrm{x}$ & $\mathrm{x}$ & & $\mathrm{x}$ & $\mathrm{x}$ & & & & $\mathrm{x}$ & $\mathrm{x}$ & $x$ & $x$ & $\mathrm{x}$ \\
\hline 2. Teams sills & $x$ & & $x$ & & $\mathrm{x}$ & $x$ & $\mathrm{x}$ & $\mathrm{x}$ & $\mathrm{x}$ & $\mathrm{x}$ & $\mathrm{x}$ & $\mathrm{x}$ & $\mathrm{x}$ & $x$ & $\mathrm{x}$ & & $\mathrm{x}$ & $x$ & $\mathrm{x}$ & $\mathrm{x}$ & & & & $\mathrm{x}$ & $\mathrm{x}$ & $\mathrm{x}$ & $x$ & $\mathrm{x}$ \\
\hline $\begin{array}{l}\text { 3. Data } \\
\text { managerencent }\end{array}$ & $x$ & $\mathrm{x}$ & $x$ & & & $\mathrm{x}$ & $\mathrm{x}$ & & $\mathrm{x}$ & & & $\mathrm{x}$ & $x$ & $\mathrm{x}$ & $\mathrm{x}$ & $\mathrm{x}$ & $\mathrm{x}$ & $\mathrm{x}$ & $\mathrm{x}$ & $\mathrm{x}$ & & & & $\mathrm{x}$ & $\mathrm{x}$ & $x$ & $x$ & $\mathrm{x}$ \\
\hline 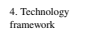 & $\mathrm{x}$ & $\mathrm{x}$ & $x$ & & & $x$ & $\mathrm{x}$ & $\mathrm{x}$ & $x$ & $\mathrm{x}$ & $x$ & $\mathrm{x}$ & & & $\mathrm{x}$ & $\mathrm{x}$ & $\mathrm{x}$ & $x$ & $\mathrm{x}$ & $\mathrm{x}$ & & & & $\mathrm{x}$ & $x$ & $x$ & $x$ & $\mathrm{x}$ \\
\hline $\begin{array}{l}\text { 5. Adequate } \\
\text { resounces }\end{array}$ & $x$ & $\mathrm{x}$ & $\mathrm{x}$ & & $\mathrm{x}$ & $\mathrm{x}$ & $x$ & $\mathrm{x}$ & $x$ & $\mathrm{x}$ & $\mathrm{x}$ & $\mathrm{x}$ & $\mathrm{x}$ & $x$ & & & $\mathrm{x}$ & $\mathrm{x}$ & $\mathrm{x}$ & $\mathrm{x}$ & & & & & $\mathrm{x}$ & $\mathrm{x}$ & $x$ & $\mathrm{x}$ \\
\hline 6. Project sopepe & $\mathrm{x}$ & $x$ & $\mathrm{x}$ & & & $\mathrm{x}$ & $\mathrm{x}$ & & $\mathrm{x}$ & $\mathrm{x}$ & $\mathrm{x}$ & & & $\mathrm{x}$ & $\mathrm{x}$ & & & $x$ & $\mathrm{x}$ & $\mathrm{x}$ & & & & $\mathrm{x}$ & $\mathrm{x}$ & $\mathrm{x}$ & $\mathrm{x}$ & $\mathrm{x}$ \\
\hline $\begin{array}{l}\text { 7. Vision and } \\
\text { requiremenast }\end{array}$ & $\mathrm{x}$ & $x$ & $\mathrm{x}$ & & & & $\mathrm{x}$ & $x$ & $\mathrm{x}$ & $\mathrm{x}$ & & & & $x$ & & & & & $\mathrm{x}$ & & & & & & $\mathrm{x}$ & $x$ & $x$ & $\mathrm{x}$ \\
\hline $\begin{array}{l}\text { 8. Executive } \\
\text { sponosor }\end{array}$ & $x$ & $x$ & $x$ & & & & & $x$ & $\mathrm{x}$ & $\mathrm{x}$ & $\mathrm{x}$ & & & $x$ & $x$ & & & $x$ & $\mathrm{x}$ & $\mathrm{x}$ & & & & & $x$ & $\mathrm{x}$ & $\mathrm{x}$ & $\mathrm{x}$ \\
\hline $\begin{array}{l}\text { 9. Stratagic } \\
\text { alignment }\end{array}$ & $\mathrm{x}$ & $x$ & $\mathrm{x}$ & $\mathrm{x}$ & $\mathrm{x}$ & $\mathrm{x}$ & & & & & & & $x$ & & & $\mathrm{x}$ & & $x$ & $\mathrm{x}$ & $\mathrm{x}$ & & & & $\mathrm{x}$ & & $x$ & $\mathrm{x}$ & $\mathrm{x}$ \\
\hline $\begin{array}{l}\text { 10. Change } \\
\text { manasegencent }\end{array}$ & $x$ & & $\mathrm{x}$ & & & & $x$ & $x$ & $\mathrm{x}$ & & & & $x$ & $x$ & $\mathrm{x}$ & $x$ & & & $\mathrm{x}$ & $\mathrm{x}$ & & & & & $\mathrm{x}$ & $\mathrm{x}$ & $x$ & \\
\hline 11. Sulacholder & $\mathrm{x}$ & & $\mathrm{x}$ & & & $\mathrm{x}$ & $\mathrm{x}$ & & & $\mathrm{x}$ & $\mathrm{x}$ & $\mathrm{x}$ & $\mathrm{x}$ & & & & & & $\mathrm{x}$ & & & & & & & & & \\
\hline $\begin{array}{l}\text { 12. Organization } \\
\text { cullure }\end{array}$ & $x$ & & & & & $\mathrm{x}$ & & $x$ & & $\mathrm{x}$ & $\mathrm{x}$ & & & & & & & & & & & & & & & & & \\
\hline Indastry & $\begin{array}{l}\text { 童 } \\
\text { 童 }\end{array}$ & 量 & 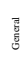 & 咅 & 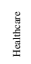 & $\begin{array}{l}\text { 高 } \\
\text { 竞 }\end{array}$ & 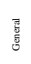 & $\frac{1}{8}$ & 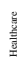 & $\begin{array}{l}\text { 童 } \\
\text { 咅 }\end{array}$ & 毫 & 竞 & 番 & $\frac{\sqrt{3}}{3}$ & 意 & 毫 & 䇋 & 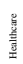 & 憘 & 量 & & & 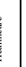 & 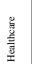 & 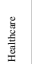 & 鏟 & 离 & $\frac{5}{3}$ \\
\hline & \multicolumn{28}{|c|}{ Authors" } \\
\hline & 29 & 30 & 31 & 32 & 33 & 34 & 35 & 36 & 37 & 38 & 39 & 40 & 41 & 42 & 43 & 44 & 45 & 46 & 47 & 48 & & & & 52 & 53 & 54 & 55 & Total \\
\hline $\begin{array}{l}\text { 1. M.Mangenent } \\
\text { support }\end{array}$ & $\mathrm{x}$ & $x$ & $\mathrm{x}$ & $\mathrm{x}$ & $\mathrm{x}$ & $\mathrm{x}$ & $\mathrm{x}$ & $\mathrm{x}$ & $\mathrm{x}$ & $\mathrm{x}$ & $\mathrm{x}$ & & & $\mathrm{x}$ & $x$ & $\mathrm{x}$ & & $\mathrm{x}$ & $\mathrm{x}$ & $\mathrm{x}$ & & & & $\mathrm{x}$ & $\mathrm{x}$ & $\mathrm{x}$ & $\mathrm{x}$ & 48 \\
\hline 2. Tram skills & $\mathrm{x}$ & $x$ & & $x$ & $x$ & $x$ & $x$ & $\mathrm{x}$ & $x$ & $\mathrm{x}$ & $\mathrm{x}$ & & & $x$ & $x$ & $\mathrm{x}$ & & $\mathrm{x}$ & $\mathrm{x}$ & $\mathrm{x}$ & & & & $\mathrm{x}$ & $x$ & $x$ & $\mathrm{x}$ & 47 \\
\hline $\begin{array}{l}\text { 3. Data } \\
\text { managesenert }\end{array}$ & $\mathrm{x}$ & $\mathrm{x}$ & $x$ & $\mathrm{x}$ & $\mathrm{x}$ & $\mathrm{x}$ & $x$ & $\mathrm{x}$ & $\mathrm{x}$ & $\mathrm{x}$ & & $x$ & & $x$ & $x$ & $\mathrm{x}$ & $x$ & & $\mathrm{x}$ & & & & & $\mathrm{x}$ & $x$ & $x$ & $\mathrm{x}$ & 46 \\
\hline $\begin{array}{l}\text { 4. Technology } \\
\text { framenorior }\end{array}$ & $\mathrm{x}$ & $\mathrm{x}$ & $\mathrm{x}$ & $\mathrm{x}$ & $\mathrm{x}$ & $\mathrm{x}$ & $x$ & $\mathrm{x}$ & $\mathrm{x}$ & $\mathrm{x}$ & & & & $\mathrm{x}$ & $\mathrm{x}$ & $\mathrm{x}$ & $\mathrm{x}$ & & $\mathrm{x}$ & $\mathrm{x}$ & & & & $\mathrm{x}$ & $\mathrm{x}$ & $\mathrm{x}$ & & 45 \\
\hline 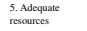 & $\mathrm{x}$ & $x$ & $\mathrm{x}$ & $\mathrm{x}$ & $\mathrm{x}$ & $\mathrm{x}$ & $\mathrm{x}$ & & $\mathrm{x}$ & & & & & $\mathrm{x}$ & $x$ & $\mathrm{x}$ & $\mathrm{x}$ & $\mathrm{x}$ & $\mathrm{x}$ & $\mathrm{x}$ & & & & $\mathrm{x}$ & $\mathrm{x}$ & $\mathrm{x}$ & $\mathrm{x}$ & 45 \\
\hline 6. Projicat scope & $\mathrm{x}$ & $\mathrm{x}$ & $\mathrm{x}$ & $\mathrm{x}$ & $\mathrm{x}$ & $\mathrm{x}$ & $\mathrm{x}$ & $\mathrm{x}$ & $\mathrm{x}$ & $\mathrm{x}$ & $\mathrm{x}$ & $\mathrm{x}$ & & $x$ & & & $\mathrm{x}$ & & & & & & & $\mathrm{x}$ & $\mathrm{x}$ & $\mathrm{x}$ & $\mathrm{x}$ & 40 \\
\hline $\begin{array}{l}\text { 7.Vision and } \\
\text { requiremenast }\end{array}$ & $\mathrm{x}$ & $\mathrm{x}$ & $\mathrm{x}$ & $x$ & $\mathrm{x}$ & & $x$ & $\mathrm{x}$ & $\mathrm{x}$ & & $\mathrm{x}$ & $\mathrm{x}$ & $\mathrm{x}$ & . & & $\mathrm{x}$ & & & $\mathrm{x}$ & $\mathrm{x}$ & & & & & $\mathrm{x}$ & & $\mathrm{x}$ & ${ }^{30}$ \\
\hline $\begin{array}{l}\text { 8. Execuive } \\
\text { sponsore }\end{array}$ & $x$ & & & & & & $x$ & & $\mathrm{x}$ & $\mathrm{x}$ & & & & $x$ & $\mathrm{x}$ & $\mathrm{x}$ & $\mathrm{x}$ & $x$ & & $\mathrm{x}$ & & & & $\mathrm{x}$ & $\mathrm{x}$ & $x$ & & 35 \\
\hline $\begin{array}{l}\text { 9. Strategicic } \\
\text { alignment }\end{array}$ & $\mathrm{x}$ & & & & & & $\mathrm{x}$ & & $x$ & $\mathrm{x}$ & & $\mathrm{x}$ & & $x$ & & $\mathrm{x}$ & $\mathrm{x}$ & & $\mathrm{x}$ & & & & & $\mathrm{x}$ & $\mathrm{x}$ & $\mathrm{x}$ & $\mathrm{x}$ & 33 \\
\hline $\begin{array}{l}\text { 10. Change } \\
\text { managencent }\end{array}$ & & & & $x$ & $\mathrm{x}$ & & $\mathrm{x}$ & & $\mathrm{x}$ & $\mathrm{x}$ & & & & & $\mathrm{x}$ & & & $\mathrm{x}$ & $\mathrm{x}$ & & & & & $\mathrm{x}$ & $\mathrm{x}$ & $\mathrm{x}$ & $\mathrm{x}$ & 28 \\
\hline 11. Salkcholder & & & $\mathrm{x}$ & $\mathrm{x}$ & $\mathrm{x}$ & $\mathrm{x}$ & $\mathrm{x}$ & & & & & & & & & & & & & & & & & & & & $\mathrm{x}$ & 15 \\
\hline $\begin{array}{l}\text { 12. Organization } \\
\text { cullure }\end{array}$ & & & & $\mathrm{x}$ & $\mathrm{x}$ & $\mathrm{x}$ & & & $x$ & & & & & & & & & $\mathrm{x}$ & & & & & & & & & & 10 \\
\hline Indatury & 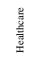 & 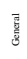 & 5 & 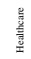 & 善 & $\frac{4}{5}$ & 粊 & 离 & $\begin{array}{l}\text { 量 } \\
\frac{1}{\underline{y}}\end{array}$ & 咅 & 喜 & 焉 & 焉 & $\frac{1}{1}$ & 毫 & 晃 & $\begin{array}{l}\text { 量 } \\
\text { 童 }\end{array}$ & 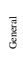 & 恶 & 要 & & & & 童 & 焉 & 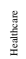 & 噽 & \\
\hline
\end{tabular}

Note*: 1 Alabaddi et al. (2020), 2 Ali, Nassif, and Capretz (2013), 3 Arnott (2008), 4 Arnott and Pervan (2005), 5 Bonney (2013), 6 Dawson and Van Belle (2013), 7 Denic et al. (2016), 8 Dubey and Sharan (2017), 9 Foshay and Kuziemsky (2014), 10 Gaardboe and Svarre (2018), 11 Gaardboe, Nyvang, and Sandalgaard (2017), 12 Gangadharan and Swami (2004), 13 Guarda et al. (2013), 14 Hawking and Sellitto (2010), 15 Hirsimäki (2017), 16 Howson (2006), 17 Hribar Rajterič (2010), 18 Isazad Mashinchi, Ojo, and Sullivan (2019), 19 Jokel, Aminy, and Klasson (2019), 20 Kasemsap (2015), 21 Krawatzeck, Dinter, and Thi (2015), 22 Lath (2018), 23 Lee (2018), 24 Loewen and Roudsari (2017), 25 Mettler and Vimarlund (2009), 26 Miah (2018), 27 Mungree, Rudra, and Morien (2013), 28 Muntean and Surcel (2013), 29 Nguyen, Meredith, and Burstein (2018), 30 Ojeda-Castro et al. (2011), 31 Olexová (2014), 32 Olszak and Batko (2012), 33 Olszak and Ziemba (2012), 34 Pejić Bach et al. (2019), 35 Pham et al. (2016), 36 Phansalkar et al. (2014), 37 Poon and Wagner (2001), 38 Popovič et al. (2012), 39 Rainer Jr. and Watson (1995), 40 Ravasan and Savoji (2019), 41 Reinschmidt and Francoise (2000), 42 Reis et al. (2019), 43 Sammon and Finnegan (2000), 44 Sangar and lahad (2013), 45 Tan et al. (2019), 46 Vizgaitytè and Rimvydas (2012), 47 Wanda and Stian (2015), 48 Wang (2013), 49 Watson and Wixom (2007), 50 Watson et al. (2004), 51 Wieder and Ossimitz (2015), 52 Wynn and Brinkmann (2016), 53 Yeoh (2008), 54 Yeoh, Gao, and Koronios (2010), 55 Yeoh and Koronios (2010) 
Figure 1. The most commonly listed critical success factors BI implementation

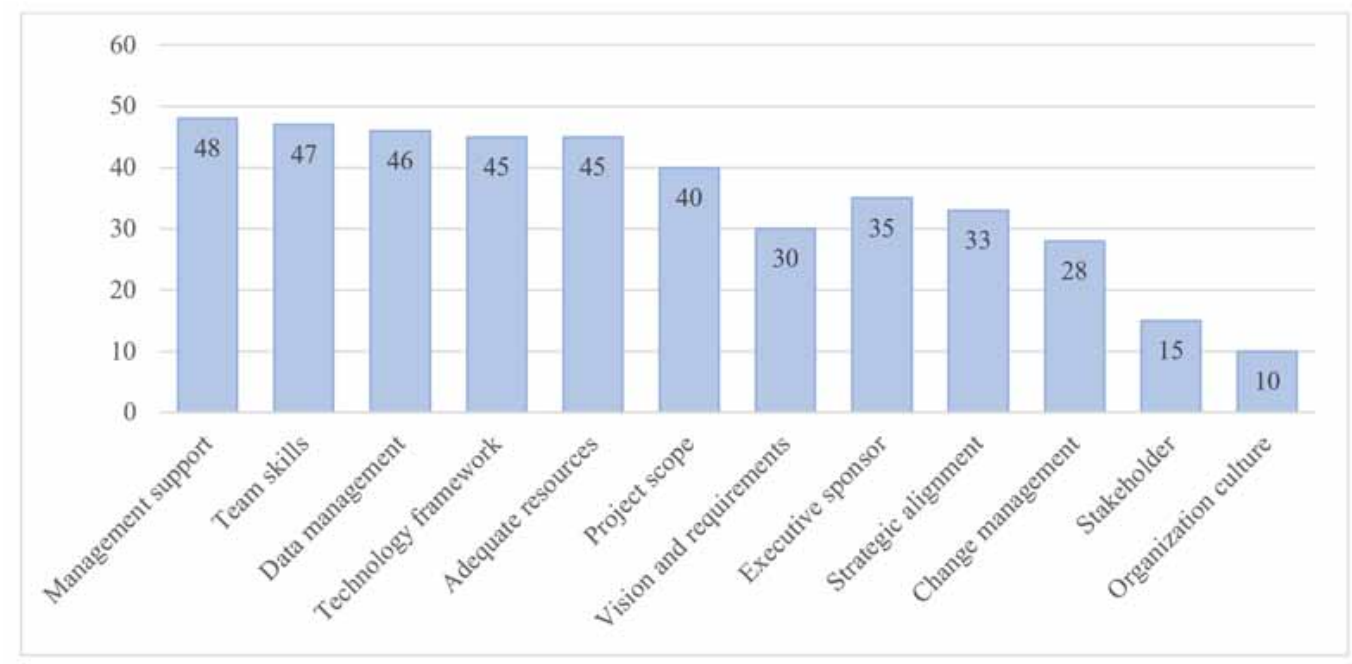

that BI projects often failed due to inadequate planning, poor project management, undelivered business requirements and/or low-quality implementations.

- Vision is essential to succeed in business. A clear vision enables BI implementation to be successful (Yeoh \& Koronios, 2010; Gaardboe \& Svarre, 2018). Senior management should have a clear vision for BI implementation, provides the necessary resources, and insists on the use of information-based decision making (Watson \& Wixom, 2007).

- Gaining a strong consenting mindset within an organization and from the executive board can also be seen as one of the greatest challenges faced by a BI implementation team (Yeoh, 2008). An official announcement for a serious BI project implementation, for instance, can set the prime policy in motion and drive the full support needed for all relevant activities leading to successful implementation.

- Strategic alignment provides a framework for decision making on what is (or is not) important to the organization, bringing harmony in planning and action. Hence, it may be considered as one of the CSFs for BI implementation (Yeoh, 2008). Yeoh \& Koronios (2010) found that if the business strategic alignment is not thoroughly understood, it will eventually impact the adoption and outcome of the BI system.

- Effective change management (CM) affects the success of BI project implementation. A structured approach or phased-out planning arrangement may be needed when dealing with the change from the use of an old system to that of a new system to ensure that changes are smoothly implemented while achieving benefits (Hawking \& Sellitto, 2010). This includes the readiness of the different partners for the normal change, and aids provided to these partners to adapt and adjust to the progress (Yeoh, 2008; Sangar \& Iahad, 2013).

- Healthcare involves a variety of stakeholders such as clinicians, payers, the government, other service providers and users (Olszak \& Batko, 2012). These healthcare stakeholders may operate on data using various information systems (Mettler \& Vimarlund, 2009). As BI is an integration among different stakeholders using different information systems, having the participation of all stakeholders is critical.

- An organizational culture is a distinct factor in BI success (Gaardboe \& Svarre, 2018). Collaboration and cross-organization commitment will contribute importantly to the success 
of BI initiatives (Alabaddi et al., 2020). Change in organizational culture is needed to ensure a successful BI implementation.

The compilation above offers a basis for considering the range of factors of success and associated frequencies for each of them. This research conducted additional analyzes via the use of qualitative research method to identify other CSFs specific to BI implementation in Thailand hospitals.

\section{RESEARCH METHODOLOGY}

In this empirical research, the 1967 Glaser-Strauss's Grounded Theory (GT), a qualitative research method, is adopted to explore the specific CSFs for BI implementation in Thailand hospitals. The GT concept was applied for data analysis and theory construction with in-depth interviews serving as the main research tools. A content analysis was also applied to reveal any hidden meanings transcribed from the interviews. Here, it is speculated that results from the in-depth interviews of all relevant hospital management and staff will help to ground new insights into the success of BI implementation in Thai hospitals.

The GT methodology involves the construction of new theory via the analysis of empirical data. On the basis of past efforts, the GT method is appropriate for cases of exploring CSFs for BI implementation in Thai hospitals as it is concerned with the generation of a theory that is 'grounded' in data that have been systematically collected and analyzed (Glaser \& Strauss, 1967). The research methodology steps are detailed in Figure 2, starting from the literature review, in Step 1, to the conclusion, in Step 5.

\subsection{Step 1: Literature Review}

As shown in Table 1, the CSFs for BI implementation in the different industries are reviewed with a total of 12 CSFs being cumulated and rationalized. Findings from this step were used to develop the interview questions in Step 2.

\subsection{Step 2: Open-Ended Questions and Opportunity Sampling Method}

The interview protocol and open-ended questions were developed to focus on the current situation and problems related to $\mathrm{BI}$ implementation in hospitals, including the CSFs for BI implementation, and the future of BI implementation. Other relevant information obtained from on-site discussions that

Figure 2. The research methodology steps

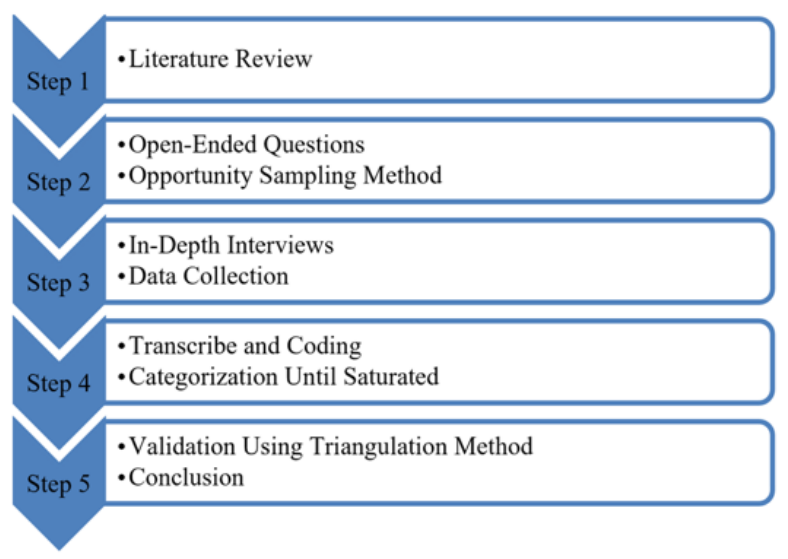


took place during the interviews include the business process of hospitals with respect to the flow of information within the hospitals, staff responsibilities, and other roles as in support peripheral staff and technicians. The target participants for the interview were determined by the opportunity sampling method, wherein participants were selected based on their availability during the interview period.

\subsection{Step 3: In-Depth Interviews and Data Collection}

According to the GT method, the in-depth interviews should be conducted over several iterations until no new aspects emerged. The target participants may be classified into three groups: 1) The service providers, which included primary care hospitals, secondary care hospitals, tertiary care hospitals, and private hospitals; 2) The policymakers and supported service organizations, which included the Ministry of Public Health and the National Health Service Support Office; and 3) Other relevant organizations, such as academic institutes, and the Thai Logistics and Production Association.

All interviews were noted and recorded with permission for further reference to the detailed answers. Other relevant data and documents were collected in line with, or after, the interviews. Overall, the in-depth interviews were conducted for 40 rounds with 24 participants. Hospital executives and IT staff were interviewed, each at least two to four times, over a period of one year.

\subsection{Step 4: Transcribe, Code and Categorize Until Saturation}

The interview notes and voice recording tapes were transcribed and key messages extracted, coded and categorized as meaningfully as possible. Then, the next round of interviews with the same participants was performed iteratively until the answers were saturated and the final versions determined to have been attained.

\subsection{Step 5: Validation via Triangulation Method and Conclusion}

The validation step to confirm results from Step 4 was conducted via the triangulation concept. Triangulation may be defined as "The combination of methodologies in the study of the same phenomenon" (Erzberger \& Kelle, 2003). It is common for results from GT studies to be validated in order to ensure the right concepts and models are generated (Glaser \& Strauss, 1967).

In the current study, the combination methods of focus group and literature review have been applied to triangulate the results from the GT. Members of the focus group were selected from key stakeholders so that the group included the most appropriate industry representatives. The focus group participants differed from the earlier interview participants for the purpose of validating the findings and gaining additional suggestions, if any. A final conclusion was then made accordingly.

\section{RESEARCH FINDINGS}

Figure 3 presents the characteristics of interview participants. Eleven (11) of the twenty-four (24) participants were IT staff at the hospitals while eight (8) were hospital executives. Five (5) government officers working at the NHSO and MOPH were also interviewed.

Sixteen (16) participants had more than 10 years of experience in hospital IT, and seven (7) participants had more than five years of experience.

Participants initially described the hospital services and processes with respect to the patients and information flow. Then the participants answered questions about their knowledge and experiences with BI applications in hospitals and the current problems. Participants then expressed their views on each of the success factors for BI implementation, and added other factors related to the hospital settings. The time required for each interview ranged from 30 to 85 minutes.

Data analyses were carried out according to the steps discussed in the research methodology. The interview transcripts and open coding were performed shortly after each interview. Then, as long as new code was found, the interviews were conducted repeatedly until no new coding emerged. 


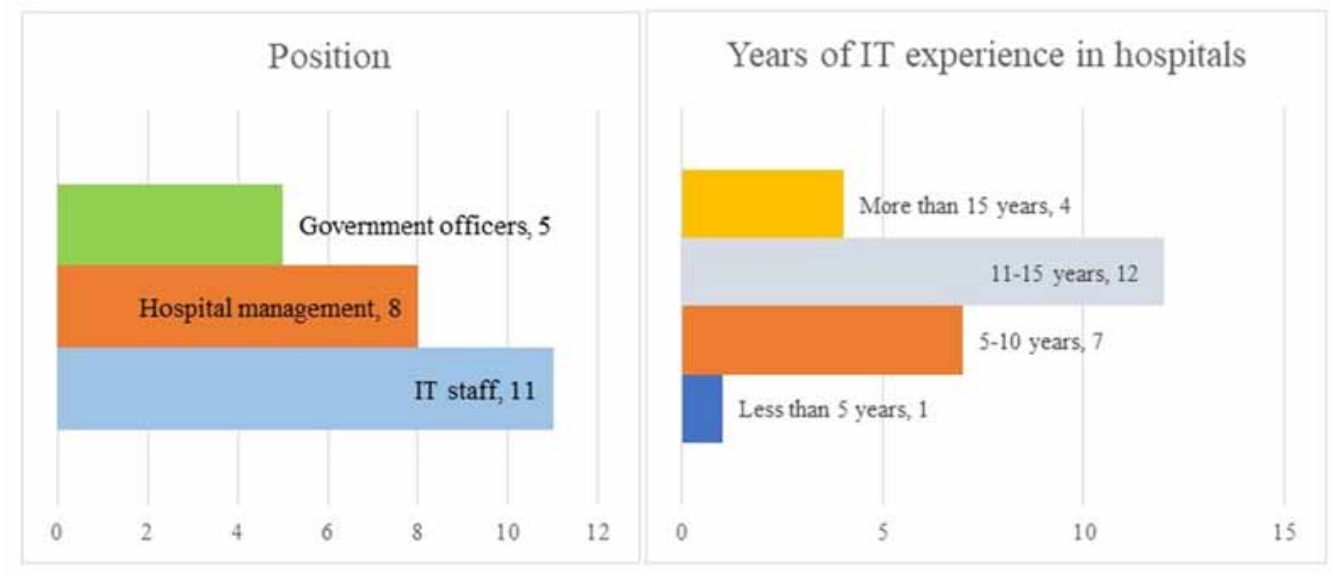

The summary of BI implementation problems in hospitals and open coding from the interviews is shown in Table 2.

Duplicate open codes in Table 2 were removed, resulting in 19 open codes that were then categorized into three groups (Major, 2014): people, process, and technology (see Table 3).

\subsection{Specific Factors for BI Implementation in Hospitals}

As shown in Table 3 and Table 4, problems coded from the interview were summarized into the specific factors for BI implementation in hospitals and later mapped with factors derived from the literature review.

For example, problems of 'the high turnover rate of IT staff in public hospitals,' first stated by participant \#1 and confirmed by another 12 participants may be grouped as a part of the IT staff retention factor whereas 'the low IT skills of hospital management,' stated by participant \#6 and confirmed later by another nine participants may be considered to form a part of the IT skills of management team factor, just as the problem of 'team skills,' which were needed to understand medical terms in addition to the IT terms, as being mentioned by 16 participants. Lastly, the problem of 'project not being really implemented' was stated by nine (9) participants, which the authors would consider as hospital-specific problems as this was not mentioned in the literature review.

Key comments from the interviews of hospital management and IT staff from the tertiary care hospitals relate to "Team skills," which was first mentioned by participant \#1:

It is quite a time-consuming process to study and understand the hospital process. This is a unique industry, which is totally different from other industries. The experience from other industries has limited applications in the hospital industry. The hospital process is also unique and contains a lot of exceptions, as the priority is not for the efficient process, but for the quality of care. A lot of technical terms are involved and need attention.

This comment is in line with the statements of participants \#9, \#14, \#20 and \#24:

It is important to integrate the work of all medical and non-medical staff in various fields so that all can learn to apply technology and innovation to improve their works. The cross-skill development is also important, as the IT staff need to know medical terms while the medical staff need to have some 
Table 2. Problems for BI implementation in hospitals: a result from interview

\begin{tabular}{|c|c|}
\hline Group of Participants & Open Coding \\
\hline Hospital management & $\begin{array}{l}\text { 1. Difficult to link data } \\
\text { 2. Lack of IT manpower } \\
\text { 3. IT skill in management team } \\
\text { 4. Insufficient IT skills in data entry staff } \\
\text { 5. High turnover rate in IT manpower } \\
\text { 6. Front and back data not connected } \\
\text { 7. Information not benefit for in-house } \\
\text { 8. Not real time in data record } \\
\text { 9. Lack of funding } \\
\text { 10. Limitations of HIS } \\
\text { 11. Reliability of information } \\
\text { 12. Limitations in upgrading HIS and other application } \\
\text { 13. Too much in data entry process } \\
\text { 14. Weak in process of transferring project BI to routine } \\
\text { 15. Physicians still use paper records } \\
\text { 16. Lack of authority } \\
\text { 17. Lack of data analytics skill }\end{array}$ \\
\hline IT staff & $\begin{array}{l}\text { 1.Difficult to link data } \\
\text { 2.Lack of IT manpower } \\
\text { 3.Insufficient IT skills in data entry staff } \\
\text { 4.High turnover rate in IT manpower } \\
\text { 5.Front and back data not connected } \\
\text { 6.More information system } \\
\text { 7.Unclear in data standard } \\
\text { 8.Information not benefit for in-house } \\
\text { 9.Not real time in data record } \\
\text { 10. Frequent change in data structure } \\
\text { 11. Limitations of HIS } \\
\text { 12. Limitations in upgrading HIS and other application } \\
\text { 13. Too much in data entry process } \\
\text { 14. Lack of data analytics skill }\end{array}$ \\
\hline Government officer & $\begin{array}{l}\text { 1. Difficult to link data } \\
\text { 2. Lack of IT manpower } \\
\text { 3. Insufficient IT skills in data entry staff } \\
\text { 4. High turnover rate in IT manpower } \\
\text { 5. Front and back data not connected } \\
\text { 6. More information system } \\
\text { 7. Unclear data standards } \\
\text { 8. Information not benefit for in-house } \\
\text { 9. Not real time in data record } \\
\text { 10. Frequent change in data structure } \\
\text { 11. Lack of funding } \\
\text { 12. Limitations in upgrading HIS and other application } \\
\text { 13. Lack of authority } \\
\text { 14. Lack of data analytics skill }\end{array}$ \\
\hline
\end{tabular}

ideas on the IT and the system. This is also considered as unique factors for BI implementations in hospitals.

Similarly, participant \#6 stated that the almost all hospital management who are medical doctors lack enough IT skills at a level to understand and communicate the requirements for the project. IT skills are also important for monitoring the project implementation, as stated by participant \#6: 
Table 3. Classification of problems using axial coding

\begin{tabular}{|l|l|}
\hline \multicolumn{1}{|c|}{ Open Coding } & Axial Coding \\
\hline 1. Lack of IT manpower & \\
2. Insufficient IT skills in data entry staff & People \\
3. High turnover rate in IT manpower & \\
4. Physicians still use paper records \\
5. Lack of data analytics skill & \\
\hline 6. Difficult to link data & \\
7. Unclear data standards & \\
8. Information not benefit for in-house & \\
9. Not real time in data record & Process \\
10. Frequent change in data structure & \\
11. Lack of funding & \\
12. Reliability of information & \\
13. Limitations in upgrading HIS and other application & \\
14. Too much in data entry process & \\
15. Weak in process of transferring project BI to routine & \\
16. Lack of authority & Technology \\
\hline 17. Front and back data not connected & \\
18. More information system \\
19. Limitations of hospital information system
\end{tabular}

Table 4. CSFs for BI implementation: Results from the interview

\begin{tabular}{|c|c|c|c|c|}
\hline Critical Success Factor & $\begin{array}{c}\text { Government } \\
\text { Officers }\end{array}$ & $\begin{array}{c}\text { Hospital } \\
\text { Management }\end{array}$ & IT Staff & $\begin{array}{c}\text { Total } \\
\text { Participants }\end{array}$ \\
\hline 1. Team skills & $\mathrm{X}$ & $\mathrm{X}$ & $\mathrm{X}$ & 16 \\
\hline 2. Executive board endorsement & - & $\mathrm{X}$ & $\mathrm{X}$ & 11 \\
\hline 3. IT skills of management team & - & $\mathrm{X}$ & $\mathrm{X}$ & 10 \\
\hline 4. IT staff retention & $\mathrm{X}$ & $\mathrm{X}$ & $\mathrm{X}$ & 13 \\
\hline 5. Management support & - & $\mathrm{X}$ & $\mathrm{X}$ & 9 \\
\hline 6. Strategic alignment & $X$ & $\mathrm{X}$ & $X$ & 13 \\
\hline 7. System requirements & $X$ & $\mathrm{X}$ & $\mathrm{X}$ & 15 \\
\hline 8. Change management & $X$ & $\mathrm{X}$ & $\mathrm{X}$ & 11 \\
\hline 9. Data management & $\mathrm{X}$ & $\mathrm{X}$ & $\mathrm{X}$ & 13 \\
\hline 10. Project scope management & $\mathrm{X}$ & $\mathrm{X}$ & $\mathrm{X}$ & 12 \\
\hline 11. Stakeholder linkage & $\mathrm{X}$ & $\mathrm{X}$ & $\mathrm{X}$ & 12 \\
\hline 12. Project transferring & $X$ & $\mathrm{X}$ & $\mathrm{X}$ & 9 \\
\hline 13. Technological framework & $\mathrm{X}$ & $\mathrm{X}$ & $\mathrm{X}$ & 16 \\
\hline 14. Resources allocation & - & $\mathrm{X}$ & $\mathrm{X}$ & 11 \\
\hline
\end{tabular}

The hospital management will better control and make use of data in case that they have sufficient IT skills to analyze data themselves. I have learnt that an IT project of a hospital nearby has never been implemented after the project completion. It is because the new management team has no IT management skills and showed no interest in the project. 
Clearly, these comments relate to IT skills of management team factor; moreover, some selected statements refer to the hospital-specific factors for BI implementation:

Most of the hospitals did not include the project implementation phase in the IT contract. They thought the implementation was not a part of project completion, and it seemed very difficult for the practical implementation of IT projects due to too many involvements and patient-oriented concern. The implementation at some time later created more headaches, as the staff involved in the beginning might resign. The IT staff turnover rate was so high.

\subsection{Validation via Triangulation}

Triangulation has often been used to facilitate validation of results from qualitative research (Jonsen \& Jehn, 2009) apart from the use of mixed methods (Erzberger \& Kelle, 2003). Here, the method was applied to affirm results from the GT method via the combined methods of a focus group and an extant literature review to triangulate the results from the GT.

Members of the focus group were selected from key stakeholders to ensure the group included the across-the-board representatives of the industry. The focus group participants were different from the earlier interviewed participants and were used to validate the findings and gain additional suggestions, if any. A total of twenty-four (24) focus group panelists participated in the discussion. Sixteen (16) IT staff from public v. private hospitals, four (4) hospital management and four (4) government officers participated. During the course of focus group discussions, some non-IT staff of the hospitals and some academic researchers who were interested in BI implementation in hospitals also participated. As a result, each of the success factors was then redefined for specific BI implementation in hospitals (see Table 5).

As another perspective of triangulation, selected healthcare literature also affirmed the study findings. Table 6 presents the result from the validation using triangulation. Apparently, all fourteen (14) factors identified would qualify as CSFs for BI implementation in hospitals.

\section{DISCUSSION}

From the validation process via triangulation, the success factors 'Team skills,' 'Executive board endorsement,' 'Management support,' 'Strategic alignment,' 'System requirements,' 'Change management,' 'Data management,' 'Project scope management,' 'Stakeholder linkage,' 'Technological framework,' and 'Resources allocation' are common factors for BI implementation in any industry.

Accordingly, the success factors 'IT skills of management team,' 'IT staff retention,' and 'Project transferring,' have not appeared in other literature and are considered as specific factors for BI implementation in Thailand hospitals.

Figure 4 summarizes the result.

\subsection{IT Skills of the Management Team}

The IT skills of the management team, a key challenge for BI implementation in Thailand hospitals, appears also to be a common factor for other industries. In Thailand, almost all hospital management personnel are medical doctors, who are well trained only in medical treatment procedures, and not IT implementation or management skills; so, it would be a plus if the hospital management staff has some IT background.

The success of BI implementation relies on the level of understanding of the hospital management who will be expected to impart the system requirements to the project staff for implementation. The outcome of a project will be based on resulting utility of the implemented systems vis-à-vis the verified requirements, and ongoing usability of the system as dependent on needed IT skills for implementation and during project monitoring. Suggestion for improvement is that the hospital management should 
Table 5. Definition of critical success factors for BI implementation

\begin{tabular}{|c|c|c|}
\hline Dimension & Critical Success Factor & Definition \\
\hline \multirow[t]{5}{*}{ People } & 1. Team skills & $\begin{array}{l}\text { The hospital staff should have knowledge, skills and experience sufficient } \\
\text { for BI implementation. }\end{array}$ \\
\hline & $\begin{array}{l}\text { 2. Executive board } \\
\text { endorsement }\end{array}$ & $\begin{array}{l}\text { The hospital executive board should be informed and endorse the } \\
\text { BI implementation project so that they can allocate funds for capital } \\
\text { investment. }\end{array}$ \\
\hline & $\begin{array}{l}\text { 3. IT skills of } \\
\text { management team }\end{array}$ & $\begin{array}{l}\text { The hospital management team needs to have sufficient IT skills to manage } \\
\text { IT project effectively. }\end{array}$ \\
\hline & 4. IT staff retention & $\begin{array}{l}\text { The hospital should have the ability to retain its employees to work for a } \\
\text { long-term, especially the IT staff. }\end{array}$ \\
\hline & 5. Management support & $\begin{array}{l}\text { The commitment and involvement of senior management are imperative } \\
\text { to help overcome resistance and manage the change process for BI project } \\
\text { implementation. }\end{array}$ \\
\hline \multirow[t]{7}{*}{ Process } & 6. Strategic alignment & $\begin{array}{l}\text { The project objectives must be aligned with the hospital's strategic vision } \\
\text { and mission. }\end{array}$ \\
\hline & 7. System requirements & $\begin{array}{l}\text { The information and system requirement for project implementation should } \\
\text { be clear. }\end{array}$ \\
\hline & 8. Change management & $\begin{array}{l}\text { The hospital should plan for change management to ensure a smooth } \\
\text { project implementation. }\end{array}$ \\
\hline & 9. Data management & $\begin{array}{l}\text { The data management should be performed correctly and effectively so } \\
\text { that the results from the BI implementation create value for the hospital } \\
\text { services. }\end{array}$ \\
\hline & $\begin{array}{l}\text { 10. Project scope } \\
\text { management }\end{array}$ & $\begin{array}{l}\text { The project implementation scope should be clearly defined for the clear } \\
\text { understanding of the relevant persons. }\end{array}$ \\
\hline & 11. Stakeholder linkage & $\begin{array}{l}\text { The stakeholders (vendors and customers) should be informed and the } \\
\text { selected data sets from the stakeholders should be linked to the hospital IT } \\
\text { system. }\end{array}$ \\
\hline & 12. Project transferring & $\begin{array}{l}\text { The hospital should carefully plan for transferring the BI project to routine } \\
\text { activities for project sustainability. }\end{array}$ \\
\hline \multirow[t]{2}{*}{ Technology } & $\begin{array}{l}\text { 13. Technological } \\
\text { framework }\end{array}$ & $\begin{array}{l}\text { The technological framework should be addressed for BI project } \\
\text { implementation. }\end{array}$ \\
\hline & 14. Resources allocation & $\begin{array}{l}\text { The hospital should have adequate resources for human and capital } \\
\text { investment. }\end{array}$ \\
\hline
\end{tabular}

have appropriate IT skill trainings or else appropriate IT professionals should be hired to serve as members of the management team.

\subsection{IT Staff Retention}

In other industries, a common success factor for BI implementation seems to be the issue of 'IT staff retention'. However, this challenge is aggravated within the hospital sector as IT staff in hospitals are often not considered to act as primary staff members nor be placed in charge of the core mission of the hospitals, which is directly related to patient care.

Moreover, the salary for IT staff is not as high as for the medical staff, and the career path is poorly defined, leading to a higher turnover rate of the IT staff in the healthcare sector $\mathrm{v}$. other industries; put simply, the hospital IT staff will not only be expected to have IT skills, but also often be assumed to have some understanding of medical terminologies. This often creates many problems 
Table 6. Validation the result

\begin{tabular}{|c|c|c|c|c|}
\hline Dimension & $\begin{array}{l}\text { Critical Success } \\
\text { Factor }\end{array}$ & $\begin{array}{l}\text { Non-Healthcare } \\
\text { Literatures }\end{array}$ & $\begin{array}{l}\text { Healthcare } \\
\text { Literatures }\end{array}$ & Focus Group Statement \\
\hline \multirow[t]{5}{*}{ People } & 1. Team skills & Gaardboe and Svarre (2018) & $\begin{array}{l}\text { Alabaddi et al. (2020), } \\
\text { Miah (2018), Isazad } \\
\text { Mashinchi, Ojo and } \\
\text { Sullivan (2019) }\end{array}$ & $\begin{array}{l}\text { Insufficient IT skills in data entry staff. Lack of data } \\
\text { analytics skill. } \\
\text { (Participants \#1, 2, 3, 4, 5, 6, 7, 8,9,14,15, 16, 17, } \\
\text { 19,23,24) }\end{array}$ \\
\hline & $\begin{array}{l}\text { 2. Executive board } \\
\text { endorsement }\end{array}$ & Gaardboe and Svarre (2018) & $\begin{array}{l}\text { Alabaddi et al. (2020), } \\
\text { Isazad Mashinchi, Ojo } \\
\text { and Sullivan (2019) }\end{array}$ & $\begin{array}{l}\text { Continuity of the persons who are in charge of IT. } \\
\text { Lack of authority. } \\
\text { (Participants \#6, 8, 9, 10,12,13,14,15,17, 19, 24) }\end{array}$ \\
\hline & $\begin{array}{l}\text { 3. IT skills of } \\
\text { management team }\end{array}$ & - & - & $\begin{array}{l}\text { Lack of data analytics skill. IT skill in management } \\
\text { team. } \\
\text { (Participants \#6, 7, 8, 9, 11, 15, 17, 18, 19,23) }\end{array}$ \\
\hline & 4. IT staff retention & - & - & $\begin{array}{l}\text { High turnover rate in IT manpower. Lack of IT } \\
\text { manpower. } \\
\text { (Participants \#1, 2, 3, 4, 5, 6, 7, 12,13,15, 16, 17, } \\
\text { 19) }\end{array}$ \\
\hline & $\begin{array}{l}\text { 5. Management } \\
\text { support }\end{array}$ & $\begin{array}{l}\text { Gaardboe and Svarre (2018), } \\
\text { Jokel, Aminy and Klasson } \\
\text { (2019) }\end{array}$ & $\begin{array}{l}\text { Alabaddi et al. (2020), } \\
\text { Reis et al. (2019), Tan et } \\
\text { al. (2019), }\end{array}$ & $\begin{array}{l}\text { Lack of funding. } \\
\text { (Participants \#6, 7, 8, 9, 10,11,12,13,14, 15) }\end{array}$ \\
\hline \multirow[t]{7}{*}{ Process } & 6. Strategic alignment & $\begin{array}{l}\text { Gaardboe and Svarre (2018), } \\
\text { Jokel, Aminy and Klasson } \\
\text { (2019), Kasemsap (2015), } \\
\text { Pejić Bach et al. (2019) }\end{array}$ & $\begin{array}{l}\text { Alabaddi et al. (2020), } \\
\text { Isazad Mashinchi, Ojo } \\
\text { and Sullivan (2019), Reis } \\
\text { et al. (2019), Tan et al. } \\
\text { (2019) }\end{array}$ & $\begin{array}{l}\text { Frequent change in data structure. } \\
\text { (Participants } \# 1,2,3,4,5,8,9,14,15,19,20,21 \text {, } \\
\text { 23) }\end{array}$ \\
\hline & $\begin{array}{l}\text { 7. System } \\
\text { requirements }\end{array}$ & $\begin{array}{l}\text { Jokel, Aminy and Klasson } \\
\text { (2019), Gaardboe and Svarre } \\
\text { (2018), Kasemsap (2015) }\end{array}$ & $\begin{array}{l}\text { Alabaddi et al. (2020), } \\
\text { Isazad Mashinchi, Ojo } \\
\text { and Sullivan (2019), Miah } \\
\text { (2018), Reis et al. (2019) }\end{array}$ & $\begin{array}{l}\text { Limitations in upgrading HIS and other application. } \\
\text { More information system. } \\
\text { (Participants \#1, 2, 3, 4, 5, 6, 7, 8, 9, 10,11,14, 15, } \\
\text { 18, 19) }\end{array}$ \\
\hline & $\begin{array}{l}\text { 8. Change } \\
\text { management }\end{array}$ & $\begin{array}{l}\text { Dubey and Sharan (2017), } \\
\text { Eybers, Hattingh, and } \\
\text { Kuoe (2019), Jokel, Aminy } \\
\text { andKlasson(2019) }\end{array}$ & $\begin{array}{l}\text { Alabaddi et al. (2020), } \\
\text { Isazad Mashinchi, Ojo } \\
\text { and Sullivan (2019) }\end{array}$ & $\begin{array}{l}\text { Physicians still use paper records. } \\
\text { (Participants \#1, 2, 5, 8, 9, 10,11,12,13,14, 15) }\end{array}$ \\
\hline & 9. Data management & $\begin{array}{l}\text { Eybers, Hattingh, and Kuoe } \\
\text { (2019), Kasemsap (2015), } \\
\text { Jokel, Aminy and Klasson } \\
\text { (2019), }\end{array}$ & $\begin{array}{l}\text { Alabaddi et al. (2020), } \\
\text { Isazad Mashinchi, Ojo } \\
\text { and Sullivan (2019), Miah } \\
\text { (2018), Reis et al. (2019) }\end{array}$ & $\begin{array}{l}\text { Information not benefit for in-house. Difficult to link } \\
\text { data. Unclear in data standard. } \\
\text { (Participants \#1, } 2,3,4,5,9,11,14,15,18,19 \text {, } \\
\text { 20, 24) }\end{array}$ \\
\hline & $\begin{array}{l}\text { 10. Project scope } \\
\text { management }\end{array}$ & Gaardboe and Svarre (2018) & $\begin{array}{l}\text { Alabaddi et al. (2020), } \\
\text { Isazad Mashinchi, Ojo } \\
\text { and Sullivan (2019) }\end{array}$ & $\begin{array}{l}\text { Linkage data in front and back office. Information } \\
\text { not benefit for in-house. } \\
\text { (Participants } \# 1,2,3,9,10,11,13,15,18,19,23 \text {, } \\
\text { 24) }\end{array}$ \\
\hline & $\begin{array}{l}\text { 11. Stakeholder } \\
\text { linkage }\end{array}$ & $\begin{array}{l}\text { Eybers, Hattingh, and Kuoe } \\
\text { (2019), Gaardboe and Svarre } \\
\text { (2018) }\end{array}$ & $\begin{array}{l}\text { Miah (2018), Isazad } \\
\text { Mashinchi, Ojo and } \\
\text { Sullivan (2019) }\end{array}$ & $\begin{array}{l}\text { Information not benefit for in-house. Frequent change } \\
\text { in data structure and reports. } \\
\text { (Participants } \# 1,2,4,5,6,9,13,15,18,19,23,24)\end{array}$ \\
\hline & $\begin{array}{l}\text { 12. Project } \\
\text { transferring }\end{array}$ & - & - & $\begin{array}{l}\text { Weak in process of transferring project BI to routine. } \\
\text { (Participants } \# 1,3,4,12,13,15,16,17,19)\end{array}$ \\
\hline \multirow[t]{2}{*}{ Technology } & $\begin{array}{l}\text { 13. Technological } \\
\text { framework }\end{array}$ & $\begin{array}{l}\text { Gaardboe and Svarre (2018), } \\
\text { Jokel, Aminy and Klasson } \\
\text { (2019), Kasemsap (2015) }\end{array}$ & $\begin{array}{l}\text { Alabaddi et al. (2020), } \\
\text { Isazad Mashinchi, Ojo } \\
\text { and Sullivan (2019), Miah } \\
\text { (2018), Reis et al. (2019), } \\
\text { Tan et al. (2019) }\end{array}$ & $\begin{array}{l}\text { Not real time in data record. Limitations of HIS. } \\
\text { Reliability of information. Limitations in upgrading } \\
\text { HIS and other application. Too much in data entry } \\
\text { process. } \\
\text { (Participants \#1, } 2,3,4,5,6,7,8,9,10,11,14,15, \\
18,19,23 \text { ) }\end{array}$ \\
\hline & $\begin{array}{l}\text { 14. Resources } \\
\text { allocation }\end{array}$ & $\begin{array}{l}\text { Gaardboe and Svarre } \\
\text { (2018) }\end{array}$ & $\begin{array}{l}\text { Alabaddi et al. (2020), } \\
\text { Isazad Mashinchi, Ojo } \\
\text { and Sullivan (2019), } \\
\text { Miah (2018), Tan et } \\
\text { al. (2019) }\end{array}$ & $\begin{array}{l}\text { Lack of IT manpower. Lack of funding. } \\
\text { (Participants \#6, 8,9,10,12,13,14,15, 17, } \\
\text { 19, 23) }\end{array}$ \\
\hline
\end{tabular}

for BI implementation projects in hospitals, for example, the well-trained resignation of hospital IT staff can gravely affect the success of BI implementation.

Hence, it is suggested that the hospitals should separate the BI function and activities into a new business unit and determine a clear career path for their IT staff. A shared service for BI activities 


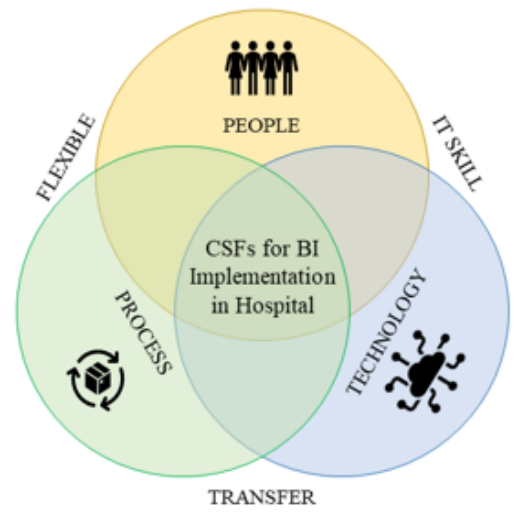

\begin{tabular}{|c|c|c|}
\hline PEOPLE & PROCESS & TECHNOLOGY \\
\hline $\begin{array}{l}\text { 1. Team skills } \\
\text { 2. Executive board } \\
\text { endorsement } \\
\text { 3. IT skills of } \\
\text { management team } \\
\text { 4. IT staff retention } \\
\text { 5. Management } \\
\text { support }\end{array}$ & $\begin{array}{l}\text { 6. Strategic alignment } \\
\text { 7. System requirements } \\
\text { 8. Change management } \\
\text { 9. Data management } \\
\text { 10. Project scope } \\
\text { management } \\
\text { 11. Stakeholder linkage } \\
\text { 12. Project transferring }\end{array}$ & $\begin{array}{l}\text { 13. Technological } \\
\text { framework } \\
\text { 14. Resources allocation }\end{array}$ \\
\hline
\end{tabular}

which consolidates the similar tasks for its member hospitals is also an option for cost saving. Special remuneration packages may be arranged for outstanding achievements.

\subsection{Project Transferring}

Another common factor for any successful BI project implementation is that of project transferring. However, this factor is special for hospitals as the mission of the hospitals is to provide the best service quality in medical care and ensure patient safety. The day-to-day work concerns the service to the patients and leaves little time for other support service activities such as IT project implementation. The process change must not affect the quality of patient care nor create errors. A good transition plan at appropriate timelines is needed for project implementation.

Importantly, the BI implementation in hospitals demands serious commitments from both hospital management and reporting staff. It is recommended that a good implementation plan should contain appropriate timeline and ongoing support during project transition. Staff involvements incentivized with extra payments from the initial launch would be an advantage. The project transferring to the new system and blending with the routine business processes must be pre-planned and agreed upon by all stakeholders prior to project initiation through to completion.

To date, guidelines for successful BI implementation have been developed. As shown in Figure 5, the three stages for BI implementation success in Thai hospitals involve: (1) overcoming BI CSFs for Thailand hospitals; (2) implementation success; and 3) system success.

In Stage 1, hospitals need to check whether their staff is ready, the process for data-driven decisions is put in place, and the appropriate technology has been selected. Both the commonly identified and hospital-specific CSFs must be assessed so that management can ensure that the project is ready to get launched. Stage 2 begins after the hospital management identifies and solves key problems and decides to implement; the success of project and technical implementation will then be evaluated. In Stage 3, system success can now be measured based on the data quality and the system quality.

\section{CONCLUSION}

Successful BI implementation in hospitals requires more than identifying the CSFs in other businesses. Even though the factors fall into the common triangle of people, process, and technology, which are the general issues to consider for any IT implementation, the insights of each category are different, and the priority placed on each factor is totally different than that in other industries. 


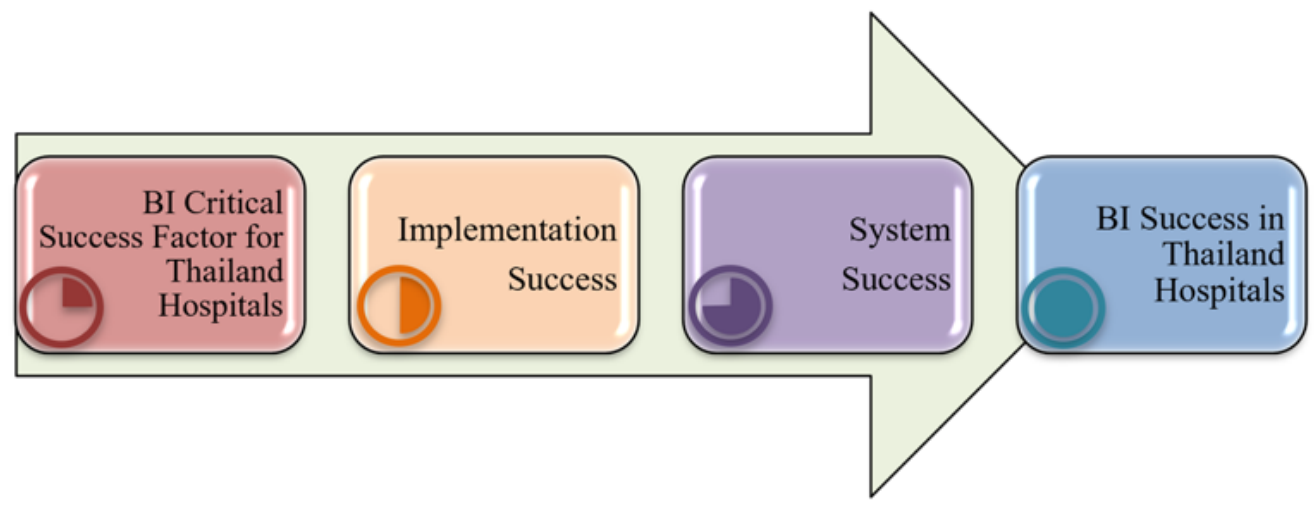

Once a hospital decides to implement a BI system, the people and the process must be considered together while the technology is more or less dictated by the IT specialists. As for the people dimension, the primary tasks and responsibilities of hospital management as a whole is to ensure that the patients, the medical professionals, and the healthcare system run efficiently. As the hospital management team plays two key roles - a medical doctor and an administrator, having a strong management support and the right IT skills set are critical for implementing BI systems successfully. Additionally, the team skills, executive board endorsement, IT staff retention, and management support are equally important factors for the successful implementation. These are in line with the CSFs found in other works, including Gaardboe \& Svarre (2018), Hirsimäki (2017), Pham, et al. (2016), Krawatzeck, Dinter \& Thi (2015), Vizgaityte \& Rimvydas (2015), Foshay \& Kuziemsky (2013) and Taylor \& Taylor (1994).

As for the process dimension, the change of the process reflects the hospital goals and management commitments. Factors relating to strategic alignment, system requirements, data management, project scope management, and stakeholder linkage are key for successful BI implementation. Conversely, from the research findings, the obstacle to the success of BI implementation in Thai hospitals is how to convert the new concept into routine jobs; hence, for successful implementation, the BI process must be blended with a hospital's routine cultures.

Today, technology, in and of itself, is not the major factor for the success of BI implementation in Thai hospitals. Yet, the use of technology requires high investments both in monetary and human capital forms. Hospitals need to design a technology framework to guide the process flow and have enough resources to implement BI efficiently. The real value of implementing BI in hospitals is in garnering all of the staff's buy-in to make better data-driven business decisions.

\subsection{Research Contribution}

Findings from this study effort provided insights into additional factors for specific BI implementation in hospitals. For instance, an important issue identified is the 'management team equipped with IT skills'. Instead of training IT staff in medical terms, the research found that the upskilling of the management team in IT skills might even be a better strategy. As the main task of hospital management is to make decisions based on their perceptions on the projects, understanding the BI concept and its benefits for the hospitals will help members of the management team to make the right decision on how to implement the BI system. This is different from other industries in which the IT staff needs to know the industry-technical terms and give advice to the management whether or not to perform BI implementation. The management themselves do not need to know the IT terms. 
Another noteworthy finding in Thai hospital settings is 'IT team sustainability.' The turnover rate of IT staff in the public hospitals appears to be relatively high vis-à-vis other industries. As a result, the IT staff shortage problem impacts the project continuity as the new staff takes some time to learn the hospital technical terms and culture. The BI implementation may not be successful without having IT team sustainability. Yet, this specific factor is not considered the critical factor for BI implementation in private hospitals as the IT staff retention rate is apparently higher than the public hospitals.

Lastly, the 'project transformation to routine jobs' is also considered a specific factor for BI implementation in Thai hospitals. As their prime commitment is on the patient care, the implementation of any new system requires a good CM in order to avoid the effect on the patients. It is painful during the transition period in which two systems are running at the same time. The BI implementation in hospitals must be pre-planned in detail for its eventual transformation into routine activities.

\subsection{Research Limitations}

A key study limitation here is that the qualitative GT method demands all coding stages within the method to require time and attention to all data. Considering other research methodologies such as the factor analysis or the multiple criteria decision-making methods such as the Analytic Hierarchy Process (AHP) or the Analytic Network Process (ANP), the importance of each critical factor relative to one another is not being investigated in the current methodology.

Another limitation is the use of opportunity sampling, where participants were selected based on their availability over the interview period. Recruiting target participants is hard when they may be unavailable for the intended study interview period; otherwise, the study may have to be seriously delayed or a larger sampling frame would be needed. Notwithstanding, the use of triangulation to affirm results from different sources via different methods was to reassure the study outcomes would be validated.

Finally, the number of participants could have increased, which may be another study limitation. For this reason, we ensure that the focus group participants differed from the participants for the interviews. Notwithstanding, increasing the number of participants would lengthy the study period with involvements of more hospitals throughout the study area. Fortunately, we were able to iterate the responses of the limited number of participants to saturation so that even if there have been an increase in the number of participants, it is expected that the outcomes to saturation would not have differed significantly.

Ultimately, as researchers gain a comprehensive knowledge of the multiple forms of limitations faced by this study, future research can further be appropriately designed to extend and/or carefully repeat the study methodological approach and analysis in order to further validate and triangulate on the outcomes of the study for the different mix of hospital staff members as well as types of healthcare organizations in different countries. This brings us to highlight on the practical implications from the findings as well as thoughts on future research directions.

\subsection{Practical Implications From the Findings}

Implementing BI in hospitals is more complicated and time-consuming than the implementation in other industries due to the focus on patient safety. The process is in need for change and strategic alignment to foster the BI implementation.

Broadly, BI implementation requires an overall organizational reengineering accompanied by internal collaboration. It should be aligned with strategic business objectives, a clear vision, well-defined information and systems requirements, $\mathrm{CM}$, effective data management, project scope management, and the conversion from the new concept into routine jobs. In term of best practices, the BI process must be blended with a hospital's routine cultures.

Even so, how well the hospitals are able to manage all the CSFs identified in this research will determine the ultimate success of BI implementation. Each of the 14 critical factors should be managed 
professionally and prepared for the practical implementation beforehand. In the end, the benefits of the BI implementation will be for the hospital customers or the patients, who will get better medical services and the best data-driven decisions for their care.

\subsection{Potential Future Research Directions}

Hospitals with different sizes serving different catchment areas may want to emphasize different factors for their successful BI implementation, given no two settings will be the exactly the same or having the same needs. Hence, future investigation can focus different on private v. public hospitals, which have different strategic targets and may also have different purposes for BI implementation. Moreover, the different hospital settings may have different limitations on the different CSFs. A comparison study for BI implementation in public v. private hospitals is also suggested for future research.

Finally, each country has a unique healthcare system and culture. Identifying the countryspecific factors for BI implementation is also interesting for future research. The applications of AHP to prioritize the critical factors can also be considered for future research topics. As well, it is recommended to develop a self-assessment check-sheet for BI implementation so that the hospitals can be prepared to be ready for change before the actual BI system implementation.

\section{ACKNOWLEDGMENT}

Jirapan Liangrokapart is the corresponding author on this paper. 


\section{REFERENCES}

Alabaddi, Z. A., Rahahleh, A. H., Alali, H., Muflih, M. A., \& Sana'a, N. A. N. (2020). The Relative Importance of The Critical Success Factors of Business Intelligence (BI) Systems Implementation in Jordanian Pharmaceutical Companies. Journal of Theoretical and Applied Information Technology, 98(12).

Ali, O. T., Nassif, A. B., \& Capretz, L. F. (2013, June). Business Intelligence Solutions in Healthcare a Case Study: Transforming OLTP System to BI Solution. In 2013 Third International Conference on Communications and Information Technology (ICCIT) (pp. 209-214). IEEE. doi:10.1109/ICCITechnology.2013.6579551

Arnott, D. (2008). Success Factors for Data Warehouse and Business Intelligence Systems. ACIS 2008 Proceedings, 16.

Arnott, D., \& Pervan, G. (2005). A Critical Analysis of Decision Support Systems Research. Journal of Information Technology, 20(2), 67-87. doi:10.1057/palgrave.jit.2000035

Bonney, W. (2013). Applicability of Business Intelligence in Electronic Health Record. Procedia: Social and Behavioral Sciences, 73, 257-262. doi:10.1016/j.sbspro.2013.02.050

Dawson, L., \& Van Belle, J. P. (2013). Critical Success Factors for Business Intelligence in the South African Financial Services Sector. South African Journal of Information Management, 15(1), 1-12. doi:10.4102/sajim. v15i1.545

Denic, N., Vujovic, V., Filic, S., \& Spasic, B. (2016). Analysis of Key Success Factors for Business Intelligence Systems Implementation. Structure, 42, 30.

Dubey, S. S., \& Sharan, A. (2017). Organizational Issue for BI Success: Critical Success Factors for BI Implementations within the Enterprise. In Handbook of Research on Advanced Data Mining Techniques and Applications for Business Intelligence (pp. 209-224). IGI Global.

Erzberger, C., \& Kelle, U. (2003). Making Inferences in Mixed Methods: The Rules of Integration. In A. Tashakkori \& C. Teddlie (Eds.), Handbook of mixed methods in social and behavioral research (pp. 457-488). Sage.

Eybers, S., Hattingh, M. J., \& Kuoe, L. (2019, September). Investigating Factors that Influence the Adoption of BI Systems by End Users in the Mining Industry in Southern Africa. In Conference on e-Business, e-Services and e-Society (pp. 113-124). Springer. doi:10.1007/978-3-030-29374-1_10

Foshay, N., \& Kuziemsky, C. (2014). Towards an Implementation Framework for Business Intelligence in Healthcare. International Journal of Information Management, 34(1), 20-27. doi:10.1016/j.ijinfomgt.2013.09.003

Gaardboe, R., Nyvang, T., \& Sandalgaard, N. (2017). Business Intelligence Success Applied to Healthcare Information Systems. Procedia Computer Science, 121, 483-490. doi:10.1016/j.procs.2017.11.065

Gaardboe, R., \& Svarre, T. A. N. J. A. (2018). Business Intelligence Success Factors: A Literature Review. Journal of Information Technology Management, 29(1), 1.

Gangadharan, G. R., \& Swami, S. N. (2004, June). Business Intelligence Systems: Design and Implementation Strategies. In 26th International Conference on Information Technology Interfaces, 2004. (pp. 139-144). IEEE.

Glaser, B. G., \& Strauss, A. L. (1967). The Discovery of Grounded Theory: Strategies for Qualitative Research. Aldine De Gruyter.

Guarda, T., Santos, M., Pinto, F., Augusto, M., \& Silva, C. (2013). Business Intelligence as a Competitive Advantage for SMEs. International Journal of Trade, Economics and Finance, 4(4), 187.

Hawking, P., \& Sellitto, C. (2010, December). Business Intelligence (BI) Critical Success Factors. In 21st Australian conference on informafion systems (pp. 1-3). Academic Press.

Hirsimäki, R. (2017). Critical Success Factors for Business Intelligence System Implementation. Academic Press.

Howson, H. (2006). Seven Pillars of BI Success - BI Tools are Getting Better, but Technology is only Part of the Story. Intelligent Enterprise, 1, 33-37.

Hribar Rajterič, I. (2010). Overview of Business Intelligence Maturity Models. Management, 15(1), 47-67. 
Isazad Mashinchi, M., Ojo, A., \& Sullivan, F. J. (2019, January). Analysis of Business Intelligence Applications in Healthcare Organizations. Proceedings of the 52nd Hawaii International Conference on System Sciences. doi:10.24251/HICSS.2019.503

Jokel, H., Aminy, B., \& Klasson, M. (2019). Self-Service Business Intelligence: Towards a CSF Model for SSBI Success (Master thesis). 15 HEC, course INFM10 in Information Systems.

Jonsen, K., \& Jehn, K. A. (2009). Using Triangulation to Validate Themes in Qualitative Studies. Qualitative Research in Organizations and Management, 4(2), 123-150. doi:10.1108/17465640910978391

Kasemsap, K. (2015). Implementing Business Intelligence in Contemporary Organizations. In Business technologies in contemporary organizations: Adoption, assimilation, and institutionalization (pp. 177-192). IGI Global. doi:10.4018/978-1-4666-6623-8.ch008

Krawatzeck, R., Dinter, B., \& Thi, D. A. P. (2015, January). How to Make Business Intelligence Agile: the Agile BI Actions Catalog. In 2015 48th Hawaii International Conference on System Sciences (pp. 4762-4771). IEEE. doi:10.1109/HICSS.2015.566

Lath, A. (2018) The Importance of Business Intelligence. Retrieved from https://www.bbntimes.com/en/ companies/the-importance-of-business-intelligence

Lee, S. Y. (2018, March). Architecture for Business Intelligence in the Healthcare Sector. In IOP Conf Ser Mater Sci Eng (Vol. 317). Academic Press.

Loewen, L., \& Roudsari, A. (2017). Evidence for Business Intelligence in Health Care: A Literature Review. Studies in Health Technology and Informatics, 235, 579-583. PMID:28423859

Major, R. (2014). People Process Technology: The Golden Triangle Explained, Halo Business Intelligence. Retrieved from https://halobi.com/blog/people-process-technology-the-golden-triangle-explained/

Mettler, T., \& Vimarlund, V. (2009). Understanding Business Intelligence in the Context of Healthcare. Health Informatics Journal, 15(3), 254-264. doi:10.1177/1460458209337446 PMID:19713399

Miah, S. J. (2018). A Demand-Driven Cloud-Based Business Intelligence for Healthcare Decision Making. In Health Care Delivery and Clinical Science: Concepts, Methodologies, Tools, and Applications (pp. 964-979). IGI Global. doi:10.4018/978-1-5225-3926-1.ch048

Mosadeghrad, A. M. (2014). Factors influencing healthcare service quality. International Journal of Health Policy and Management, 3(2), 77-89. doi:10.15171/ijhpm.2014.65 PMID:25114946

Mungree, D., Rudra, A., \& Morien, D. (2013). A Framework for Understanding the Critical Success Factors of Enterprise Business Intelligence Implementation. Academic Press.

Muntean, M., \& Surcel, T. (2013). Agile BI-The Future of BI. Informatica Economica, 17(3).

Nguyen, Q., Meredith, R., \& Burstein, F. (2018). A Comparative Study of Critical Success Factors for General and Healthcare Business Intelligence Systems. ACIS 2018 Proceedings, 4.

Ojeda-Castro, Á., Ramaswamy, M., Rivera-Collazo, Á., \& Jumah, A. (2011). Critical Factors for Successful Implementation of Data Warehouses. Issues in Information Systems, 12(1), 88-96.

Olexová, C. (2014). Business Intelligence Adoption: a Case Study in the Retail Chain. WSEAS Transactions on Business and Economics, 11(1), 95-106.

Olszak, C. M., \& Batko, K. (2012). Business Intelligence Systems. New Chances and Possibilities for Healthcare Organizations. Proceedings of Federated Conferences on Computer Science and Information Systems. Informatyka Ekonomiczna, 25, 123-138.

Olszak, C. M., \& Ziemba, E. (2012). Critical Success Factors for Implementing Business Intelligence Systems in Small and Medium Enterprises on the Example of Upper Silesia, Poland. Interdisciplinary Journal of Information, Knowledge, and Management, 7(2), 129-150. doi:10.28945/1584

Pejić Bach, M., Bosilj Vukšić, V., Suša Vugec, D., \& Stjepić, A. M. (2019). BPM and BI in SMEs: The Role of BPM/BI Alignment in Organizational Performance. International Journal of Engineering Business Management, 11, 1847979019874182. doi:10.1177/1847979019874182 
Pham, Q. T., Mai, T. K., Misra, S., Crawford, B., \& Soto, R. (2016, July). Critical Success Factors for Implementing Business Intelligence System: Empirical Study in Vietnam. In International Conference on Computational Science and Its Applications (pp. 567-584). Springer. doi:10.1007/978-3-319-42092-9_43

Phansalkar, S., Zachariah, M., Seidling, H. M., Mendes, C., Volk, L., \& Bates, D. W. (2014). Evaluation of Medication Alerts in Electronic Health Records for Compliance with Human Factors Principles. Journal of the American Medical Informatics Association: JAMIA, 21(e2), e332-e340. doi:10.1136/amiajnl-2013-002279 PMID:24780721

Poon, P., \& Wagner, C. (2001). Critical Success Factors Revisited: Success and Failure Cases of Information Systems for Senior Executives. Decision Support Systems, 30(4), 393-418. doi:10.1016/S0167-9236(00)00069-5

Popovič, A., Hackney, R., Coelho, P. S., \& Jaklič, J. (2012). Towards Business Intelligence Systems Success: Effects of Maturity and Culture on Analytical Decision Making. Decision Support Systems, 54(1), 729-739. doi:10.1016/j.dss.2012.08.017

Rainer, R. K. Jr, \& Watson, H. J. (1995). What Does It Take for Successful Executive Information Systems? Decision Support Systems, 14(2), 147-156. doi:10.1016/0167-9236(94)00008-G

Ravasan, A. Z., \& Savoji, S. R. (2019). Business Intelligence Implementation Critical Success Factors. In Applying Business Intelligence Initiatives in Healthcare and Organizational Settings (pp. 112-129). IGI Global. doi:10.4018/978-1-5225-5718-0.ch006

Reinschmidt, J., \& Francoise, A. (2000). Business Intelligence Certification Guide. IBM International Technical Support Organization.

Reis, R., Mendonça, A., Ferreira, D. L. A., Peixoto, H., \& Machado, J. (2019). Business Intelligence for Nutrition Therapy. In Healthcare Policy and Reform: Concepts, Methodologies, Tools, and Applications (pp. 459-474). IGI Global. doi:10.4018/978-1-5225-6915-2.ch022

Sammon, D., \& Finnegan, P. (2000). The Ten Commandments of Data Warehousing. ACM SIGMIS Database: the DATABASE for Advances in Information Systems, 31(4), 82-91. doi:10.1145/506760.506767

Sangar, A. B., \& Iahad, N. B. A. (2013). Critical Factors that Affect the Success of Business Intelligence Systems (BIS) Implementation in an Organization. International Journal of Scientific \& Technology Research, 2(2), 176-180.

Tan, C. S., Cheng, W. K., Ren, J., \& Wong, S. F. (2019). Business Intelligence Maturity Framework. In Applying Business Intelligence Initiatives in Healthcare and Organizational Settings (pp. 44-63). IGI Global. doi:10.4018/978-1-5225-5718-0.ch003

Taylor, R. J., \& Taylor, S. B. (Eds.). (1994). The AUPHA Manual of Health Services Management. Jones \& Bartlett Learning. Retrieved from https://books.google.co.th/books/about/The_AUPHA_Manual_of_Health_ Services_Mana.html?id=brNVoVqLNjQC\&redir_esc=y

Vizgaitytė, G., \& Rimvydas, S. (2012). Business Intelligence in the Process of Decision Making: Changes and Trends. Ekonomika (Nis), 91(3), 147-157. doi:10.15388/Ekon.2012.0.881

Wanda, P., \& Stian, S. (2015). The Secret of My Success: An Exploratory Study of Business Intelligence Management in the Norwegian Industry. Procedia Computer Science, 64, 240-247. doi:10.1016/j. procs.2015.08.486

Wang, M. (2013). Predefined Three Tier Business Intelligence Architecture in Healthcare Enterprise. Journal of Medical Systems, 37(2), 9928. doi:10.1007/s10916-013-9928-5 PMID:23334840

Watson, H. J., Abraham, D. L., Chen, D., Preston, D., \& Thomas, D. (2004). Data Warehousing ROI: Justifying and Assessing a Data Warehouse. Business Intelligence Journal, 9, 6-17.

Watson, H. J., \& Wixom, B. H. (2007). The Current State of Business Intelligence. Computer, 40(9), 96-99. doi:10.1109/MC.2007.331

Wieder, B., \& Ossimitz, M. L. (2015). The Impact of Business Intelligence on the Quality of Decision Making-a Mediation Model. Procedia Computer Science, 64, 1163-1171. doi:10.1016/j.procs.2015.08.599 
Wynn, M. G., \& Brinkmann, D. (2016). Exploiting Business Intelligence for Strategic Knowledge Management: A German Healthcare Insurance Industry Case Study. International Journal of Business Intelligence Research, 7(1), 11-24. doi:10.4018/IJBIR.2016010102

Yeoh, W. (2008). Critical Success Factors for Implementation of Business Intelligence Systems in Engineering Asset Management Organizations (Ph.D.). University of South Australia.

Yeoh, W., Gao, J., \& Koronios, A. (2010). Empirical Investigation of Critical Success Factors for Implementing Business Intelligence Systems in Multiple Engineering Asset Management Organizations. In Strategic Information Systems: Concepts, Methodologies, Tools, and Applications (pp. 2039-2063). IGI Global.

Yeoh, W., \& Koronios, A. (2010). Critical Success Factors for Business Intelligence Systems. Journal of Computer Information Systems, 50(3), 23-32.

Suwat Janyapoon is a full time lecturer in the college of Logistics and Supply Chain, Sripatum University Thailand, He received his bachelor degree in Industrial Management from Thammasat University, MBA. from Kasetsart University. At present he is a Ph.D. candidate in Logistics and Engineering Management Program, Department of Industrial Engineering, Faculty of Engineering, Mahidol University. His research interests are in area of logistics and supply chain management and healthcare supply chain.

Jirapan Liangrokapart is full time lecturer and the director of Doctor of Philosophy Program in Logistics and Engineering Management, Faculty of Engineering, Mahidol University, Thailand. She received her bachelor degree in Pharmaceutical Science from Chulalongkorn University in 1990, MBA. From Thamasat University in 1997 and Ph.D. in Industrial Engineering from Clemson University in 2001. Her research interests are in area of supply chain and logistics management, performance measurement, healthcare logistics and engineering management.

Albert Tan is currently the Director for Education in MISI and associate researcher at MIT CTL. Prior to that, he was an Associate Director managing the Master program in Supply Chain Management and Logistics Management. His research works have been published in international journals and is an editorial board member for various international journals. Albert was previously a Director working in a government agency responsible for upgrading the IT capability of the manufacturing and logistics industries. This involved planning and evaluating e-Commerce solutions for the chemical and logistics industries. He has also provided numerous ERP and Reengineering consulting services for both discrete and process environment in Asia to streamline their supply chain while working for an IT vendor. 